\title{
LABORTATORY DIAGNOSIS OF RUMINANTS BRUCELLAE BY AMOS PCR
}

\author{
${ }^{*} E N A N Y, M$. E., ${ }^{* *} A B D-E l G A L I L, Y .,{ }^{* * *} Y O U S S E F$, H.M. \\ AND ASAWY A. M. E \\ ${ }^{*}$ Department of bacteriology, Immunology and Mycology, Fac. Vet, Med. Suez Canal University. \\ ${ }^{* *}$ Fac. Vet Med. Zagazig University and General Organization of Veterinary Services (Microbiologist)
}

\begin{abstract}
Four hundred twenty two blood, molk, tissue specimens and stomach content of aborted foeti collected from different localities at Sharkia Governorates were examined for detection of brucellae by PCR, 5 out of 110 blood samples proved to be positive, 8 out of 90 milk samples were also positive 7 out of 220 tissus specimens (4 from lymph nodes, 2 from spleen and one from stomach content of aborted foetus). Proved to harboue brucellae
\end{abstract}

\section{INTRODUCTION}

The AMOS PCR assay is based on the insertion of the genetic element insertion sequence (IS 711) at a unique chromosomal losus of brucella Species. The AMOS PCOR assay is a multiplex primer assay that was used of five-primer cocktail one primers annels to the IS 711 element, while each of the other four primer hybridized to one of the brucella species at a locus near by and at variable distanecs outside the element. Highly sensitive and specitic diagnostic test for brucella based on PCR.(Fekete et al,1990) a suitable reaction conditions and oligonucleotide primers for the detecion of B. melitensis and B. abortus by PCR and the technique proved be applicable in the diagnosis of brucellosis (Bailey et al, 1992). PCR proved to be faster than bacteriological tests and more accurate than imminologic methods because it directly detected the presence of the organism (Fekete et al, 1992 (Ouahrani-Bettache et $a l, 1993)$, Isolated an IS element of $B$. ovis and named is6501. PCR assay comprises fine oligonucleotide primers which can identify selected biovars four species are Brucella. Individual biovars within species species are not differentiated. The assay can identify three biovats (1.2 and 4) of B. abortus. All biovar of B. melitensis, biovar 1 of B.suis and all biovar of B.ovis.(Bricker and halling 1994). The specificity and high sensitivity of the PCR may provide a valuable tool for the diagnosis of brucellosis. 
(Romero et al, 1995). The specificities of PCR ELISA were 100\%. When testing milk samples form beucella, free cattle. A PCR positive sample was negative by ELISA and 7 ELISA-poaitive Were PCR negative. The specificities of both tests, were $100 \%$ while sensitity was 98\%. (Romero et al, 1995). The possibitity of using polymerase chain reation (PCR) for the laboratory diagnosis of brucellosis with representative regional collection of 44 brucella strains. (Balakhonov et al, 1996).

All species of genus brucella contain several copies (between10- 40) of an insertion sequence appears of IS 711. The position of copies of this insertion sequence appears to differ in each species and this can be used to discriminate between them. The obtained patterns reflect the position of the insertion sequence in genome-this method can be used to different species, strains, within a species. (Ouahrani-Bettache et al, 1996). AMOS PCR evaluated to determine two hundreds thirty one isolates and tested them by the conventional tests and brucella AMOS PCR. (Ewalt and Bricker 2000).

This study was detect one the efficacy of PCR in the laboratory of Brucella in ruminants bred in Sharkia Governorate.

\section{MATERIALS \& METHODS}

Three $\mathrm{ml}$ aliquots blood samples from each animal, creamy sediment mixure of milk from dairy animal and specimens of tissue were obtained form slaughtered animals as well as two stomach content of aborted foeti were examined as shown in table (1).

\section{Blood samples: (leal-Kleve zas et al,)}

Four hundreds microliers of blood samples were taken and centrifuged as $4000 \times \mathrm{g}$ for $3 \mathrm{~min}$, the cell pellets were resuspended $\mathrm{HCO}_{3}, 100 \mathrm{~m}$ MEDTA (PH 7.4). Mixed and centrifuged at $4000 \times \mathrm{g}$ for 3 min.treatment with erythros lysis solution was repeated until the leukocyt e pellets lost all reddish colouring. $10 \mathrm{ul}$ of proteinase $\mathrm{k}(20 \mathrm{mg} / \mathrm{ml})$ were added to the sample and mixed thoroughly and incubated for $30 \mathrm{~min}$. at $50^{\circ} \mathrm{C} .400 \mathrm{ul}$ of 5 asturated phenol was mixed and centrifuged ar $8000 \times \mathrm{g}$ for $5 \mathrm{~min}$, the aqueous layer was transferred to a fresh tube and equal volume of chloroform- isoamyl alcohol was added and centrifuged at $8000 \mathrm{xg}$ for $5 \mathrm{~min}$. The aqueous layer was transferred to a fresh tube and $7.5 \mathrm{M}$

$\overline{\text { Kafr El-Sheikh Vet. Med. J. Vol. } 1 \text { No. } 1 \text { (2003) }}$ 
ammonium acetate was added, the two volume of $95 \%$ ethanol was added and centrifuged at $8000 \mathrm{xg}$ for $5 \mathrm{~min}$. The pellets were rinsed with $20 \mathrm{ul}$ of TE buffer (10 mM) Tris HCL (PH. 80), $1 \mathrm{~m}$ Mdisodium EDTA).

\section{Milk samples:-}

Frozen milk was thawed at room temperature and $400 \mathrm{ul}$ from fatty layer was mixed with $400 \mathrm{ul}$ of lysis solution (2\%) Triton $\times-100,1 \%$ sodium dodecyl sulfate, $100 \mathrm{~m}$ M NACL, 10m Tris-HCL (PH. 8.0) and $10 \mathrm{ul}$ of proteinase $\mathrm{K}(20 \mathrm{mg} 1 \mathrm{ml})$ were added and incubated for $30 \mathrm{~min}$ at $50^{\circ} \mathrm{C}$ then proceed as in blood samples.

Tissue samples (Rambrook et al, 1989):

Freshly excised tissue was dropped in liquid nitrogen cup and grinded in pestle and morter. 10 volumes of extraction buffer $(10 \mathrm{mM}$ Tris- HCL (PH 8.0), 1.0 MEDTA (PH. 8.0), $20 \mathrm{ug} / \mathrm{ml}$ pancreatic Rnase and $0.5 \%$ SDS) in a beaker., put in $15 \mathrm{ml}$ centrifuge tube, incubated for 1 hour at $37^{\circ} ., 10 \mathrm{ul}$ of proteinase $\mathrm{k}(20 \mathrm{mg} / \mathrm{ml})$ was added and the contenrts were mixed and incubated for $30 \mathrm{~min}$. at $50^{\circ} \mathrm{C}$, then proceed as in blood samples.

\section{Determination of DNA concentration:}

Was determined by measuring optical density via absorbance measurement at $260 \mathrm{~nm}$ and $280 \mathrm{~nm}$. (Sam brook et al, 1989).

\section{Amplifion by PCR: (leal-kleve zas et al 1995)}

The brucella PCR diagnostic assay primer cocktail composed of Five primers were published by (Bricker and Halling 1994) and Was performed in a toatal of $50 \mathrm{ul}$ with $100 \mathrm{ng}$ of DNA, $50 \mathrm{pmol}$ of Each primer, $50 \mathrm{mM}$ KCL, $10 \mathrm{Mm}$ Tris-HCL (PH 9.0), 0.1\% Triton $\times-100,3 \mathrm{~m}$ $\mathrm{M} \mathrm{Mg} \mathrm{CL} 2,200 \mathrm{uM}$ (each) DNTPS and $2.5 \mathrm{u}$ Taq. Polymerase. The reaction was conducted in DNA the thermal cycler (Perkin Eimer, syster 2400). At a denaturation temperature $94^{\circ}$ for $4 \mathrm{~min}$., this was followed 35 cycles at $94^{\circ}$ for $60 \mathrm{sec}$., $60^{\circ} \mathrm{C}$ for $60 \mathrm{sec}$. AND $72^{\circ} \mathrm{C}$ for $60 \mathrm{sec}$. and one final extension at $72^{\circ} \mathrm{c}$ for $3 \mathrm{~min}$ before stored at $4^{\circ} \mathrm{C}$. Eight microliters of the amplified reaining mixture were taken taken and fractionated in a $1.5 \%$ agarose gel staining with ethidium bromide comide containg $1 \times \mathrm{TBE}$ and 100-bp DNA ladder as asize standard, than electrophoreaed at $75 \mathrm{~V}$ for 1.5 hours and photographed over Uv light source. 
Table (1) Number of samples examined by PCR assay:

\begin{tabular}{|c|c|c|c|c|c|c|c|}
\hline \multirow{2}{*}{$\begin{array}{l}\text { Animal } \\
\text { Species }\end{array}$} & \multirow[b]{2}{*}{$\begin{array}{l}\text { No .of Examined } \\
\text { Blood samples }\end{array}$} & \multirow{2}{*}{$\begin{array}{c}\text { No. of } \\
\text { Milk } \\
\text { samples }\end{array}$} & \multicolumn{3}{|c|}{ No of tissue specimems } & \multirow{2}{*}{$\begin{array}{l}\text { No.of stomach } \\
\text { content of } \\
\text { aborted foeti }\end{array}$} & \multirow[b]{2}{*}{ Total } \\
\hline & & & $\begin{array}{c}\text { Lymph } \\
\text { nodes }\end{array}$ & spleen & uterus & & \\
\hline "Cattle & $\overline{50}$ & 35 & 48 & 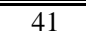 & 8 & - & 177 \\
\hline Sheep & 24 & 23 & 21 & 20 & 6 & 1 & 95 \\
\hline Goats & 29 & 24 & 27 & 25 & 7 & 1 & 118 \\
\hline Camels & 7 & 8 & 7 & 7 & 3 & - & 32 \\
\hline Total & 1110 & 90 & 103 & 93 & 24 & 2 & 422 \\
\hline
\end{tabular}

\section{RESULTS \& DISCUSSION}

One strain amplified 498- bp fragment out of 50 cattle blood samples and identified as B. abortus, one strain from 24 sheep blood samples and amplified 731-bp fragments and identified as B. meliensis and three strins were amplified a 731- bp fragments out of 29 goats blood samples. While camel samples proved to be brucelle free. As shown in (Table 2) figures $1 \& 2$. Eight samples milk from a total 90 samples proved to be positive be PCR (3 samples of cow's milk, one amplified 498 -bp fragment and two amplifie 731-bp feagments in an incidence of $10 \%$, two amplifie 731-bp feagments from 23 ewes milk samples in an incidence 8.69, and three amplified 731-bp fragments from 29 gaots milk sampled in an incidence of $10.34 \%$. (Table 3) Concerning examined tissue specimens by PCR, only one sample out of 97 tissue specimens of cattle (lymph node) was amplified 498-bp fragments with an incdence of $1.03 \%$, one strain was detected from 47 tissue specimens of sheep (lymph rode) and amplified 731-bp fragments with an incidence of $2.13 \%$. In addition to four straina were recovered from 59 tissue specimens of goats (2lymph nodes and 2apleen), all amplified 731-bp fragment and with an incidence of $6.78 \%$.One samole of stomach contents aborted foetus for sheep was amplified 731-bp fragment and proved to be $B$. Melitensis as ahown is table (4).

With a meticulous visiona, the PCR assay is useful technique for Direct detection of brucellae in clinical samples and proved to be Apowerful, sensitive, specific and quick than a culture, reducing The time of diagnosis to one day and providing ability to detect organism even when become non- vialable and there conclusion suported by the findings obtained by Bricker and Halling 1995, leal klevezasetal 1995 and 2000, Romero et al 1995 andEwalt and Bricker2000 who proved that PCR was optimal tool for both screening of herds, testing of Kafr El-Sheikh Vet. Med. J. Vol. 1 No. 1 (2003) 
individual animal and obtain adefinitive diagnosis during acute, chronic stage of illness and before antibodies are detectable.

Table (2):Results of PCR on blood samples of examined ruminants for the detection of brycellae.

\begin{tabular}{|c||c||c||c||c||c||c||c||}
\hline $\begin{array}{c}\text { Animal } \\
\text { Species }\end{array}$ & $\begin{array}{c}\text { No. of } \\
\text { examined } \\
\text { samples }\end{array}$ & $\begin{array}{c}\text { No. of } \\
\text { Positive } \\
\text { samples }\end{array}$ & $\%$ & $\begin{array}{c}\text { Amplication } \\
\text { fragments }\end{array}$ & $\begin{array}{c}\text { Identified } \\
\text { strain }\end{array}$ & $\begin{array}{c}\text { No. of negative } \\
\text { samples }\end{array}$ & $\%$ \\
\hline \hline Cattle & 50 & 1 & 2.00 & $498-b p$ & B. abortus & 49 & 98 \\
Sheep & 24 & 1 & 4.17 & $731-b p$ & B.melitensis & 23 & 95.83 \\
Goats & 29 & 3 & 10.3 & $731-$ bp & B.melitensis & 26 & 89.66 \\
Camels & 7 & - & 4 & - & - & 7 & 100 \\
\hline \hline Total & 110 & 5 & 4.55 & - & - & 105 & 95.45 \\
\hline
\end{tabular}

Table(3): Results of PCR on milk samples of examined ruminants for the detection of brucellae.

\begin{tabular}{||l||c||c||c||c||c||c||c||}
\hline $\begin{array}{c}\text { Animal } \\
\text { species }\end{array}$ & $\begin{array}{c}\text { No. of } \\
\text { examined } \\
\text { samples }\end{array}$ & $\begin{array}{c}\text { No. of } \\
\text { Positive } \\
\text { samples }\end{array}$ & $\%$ & $\begin{array}{c}\text { Amplification } \\
\text { fragments }\end{array}$ & $\begin{array}{c}\text { Identified } \\
\text { Strain }\end{array}$ & $\begin{array}{c}\text { No. of } \\
\text { negative } \\
\text { Ssmples }\end{array}$ & $\%$ \\
\hline \hline & & & & & & & \\
Cow & 30 & 3 & 10.00 & $498-\mathrm{bp}(1) 731-$ & B.abortus B. & 27 & 90.00 \\
Ewes & 23 & 2 & 0.69 & $\mathrm{bp}(2)$ & melitensis & 21 & 91.30 \\
Goats & 29 & 3 & 10.34 & $731-\mathrm{bp}$ & B. melitensis & 26 & 89.66 \\
She-camels & 8 & - & & $731-\mathrm{bp}$ & B. melitensis & 8 & 100.00 \\
\hline Total & 90 & 8 & 8.89 & - & - & 82 & 91.11 \\
\hline
\end{tabular}

Table (4): Results of PCR on tissue specimens and stomach contents of abortes foeti of ruminants for the detection of bruecellae.

\begin{tabular}{|c|c|c|c|c|c|}
\hline $\begin{array}{l}\text { Animal } \\
\text { species }\end{array}$ & $\begin{array}{c}\text { No.of } \\
\text { examined } \\
\text { tissue } \\
\text { specimens }\end{array}$ & $\begin{array}{c}\text { No.of } \\
\text { stomach } \\
\text { content } \\
\text { of foeti }\end{array}$ & $\begin{array}{l}\text { No. of } \\
\text { positive } \\
\text { samples }\end{array}$ & $\begin{array}{c}\text { Amolification } \\
\text { fragments }\end{array}$ & $\begin{array}{l}\text { Identified } \\
\text { strain }\end{array}$ \\
\hline Cattle & $\overline{97}$ & - & 1 & $\overline{798-b p}$ & B. abortus \\
\hline Sheep & 47 & 1 & 2 & 731-bp & B. melitensis \\
\hline Goats & 59 & 1 & 4 & 731-bp & B. melitensis \\
\hline Camels & 17 & . & . & & \\
\hline Total & 220 & 2 & 7 & - & - \\
\hline
\end{tabular}

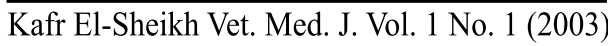


Labortatory Diagnosis Of Ruminants Brucellae By Amos PCR

Detection of Brucella in a Cattle and Sheep blood samples By Multiplex AMOSPCR assay

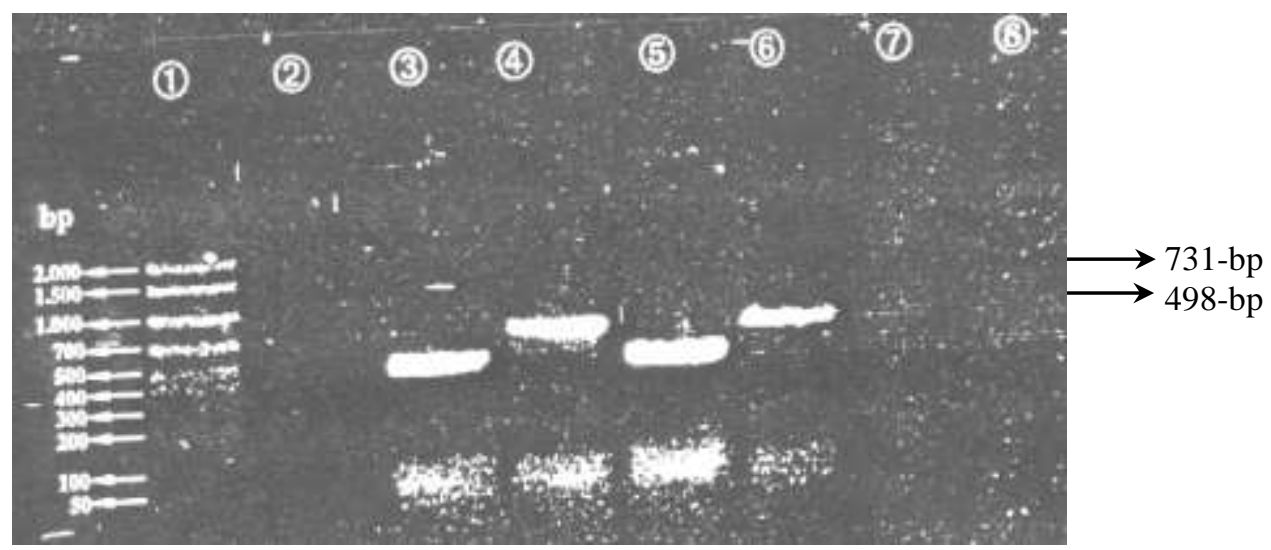

Figure(1): Lane 1:100 bp as a size atandard, Lane 2: negative control (buffer containing no template ), Lane 3: positive control (Brucella abortus 544), Lane4:positive conteol (Brucella melitensis 16M), Lane 5:Amplitied 498-bp fragment (cattle blood Sample), Lane 6:Amplified 731-bp fragment (sheep blood sa mple), Lanes 7,8: negative .

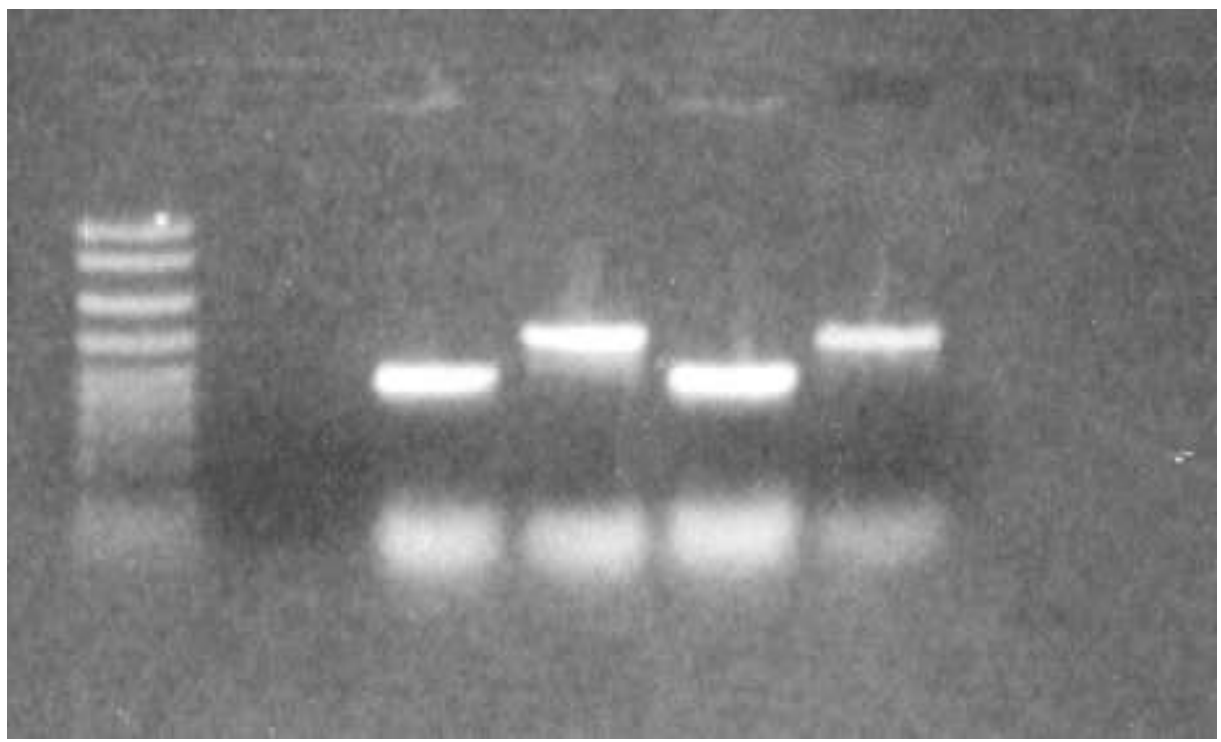

Figurd(1):Original ultraviolet photograph stained with Ethidium bromide on 1.5\% agarose ge1.

$\overline{\text { Kafr El-Sheikh Vet. Med. J. Vol. } 1 \text { No. } 1 \text { (2003) }}$ 
Detection of Brucella melitensis in three blood samples of goats by Multiplex AMOS PCR assay

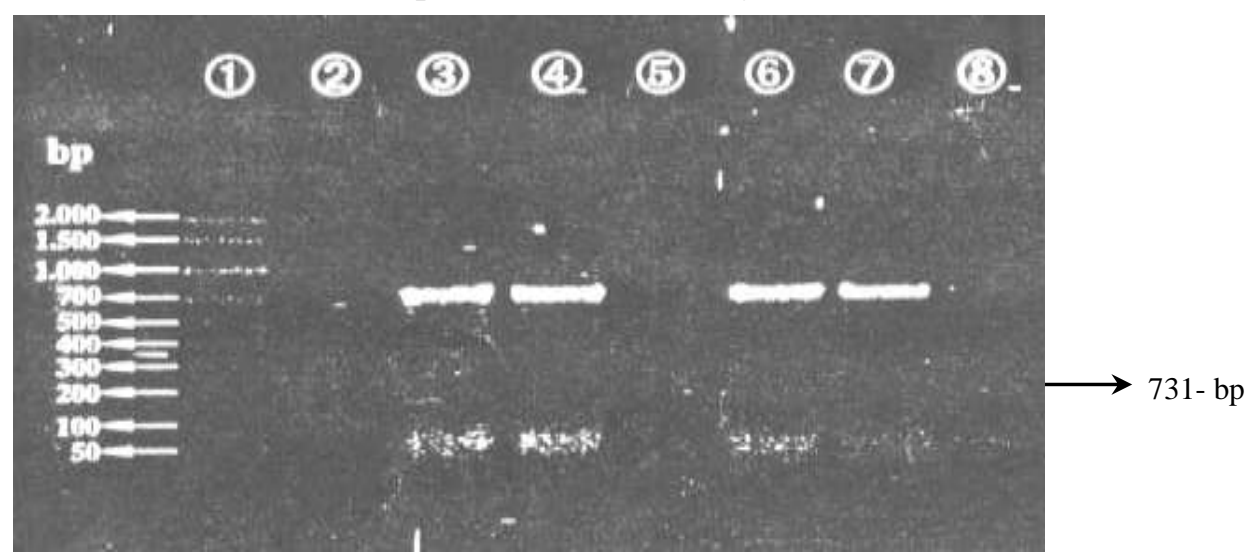

Figure (2): Lane 1:100bp ladder as a size standard, Lane 2: negative control (buffer containing no templaet), Lane 3: positive control (Brucella melitensis 16M), Lane4: Amplified 731-bp fragment, Lanes 5,8: negative, Lanes 6,7: Amplified 731-bp Fragments, products of less than 100-bp were presumed to be primer-dimer coplexes

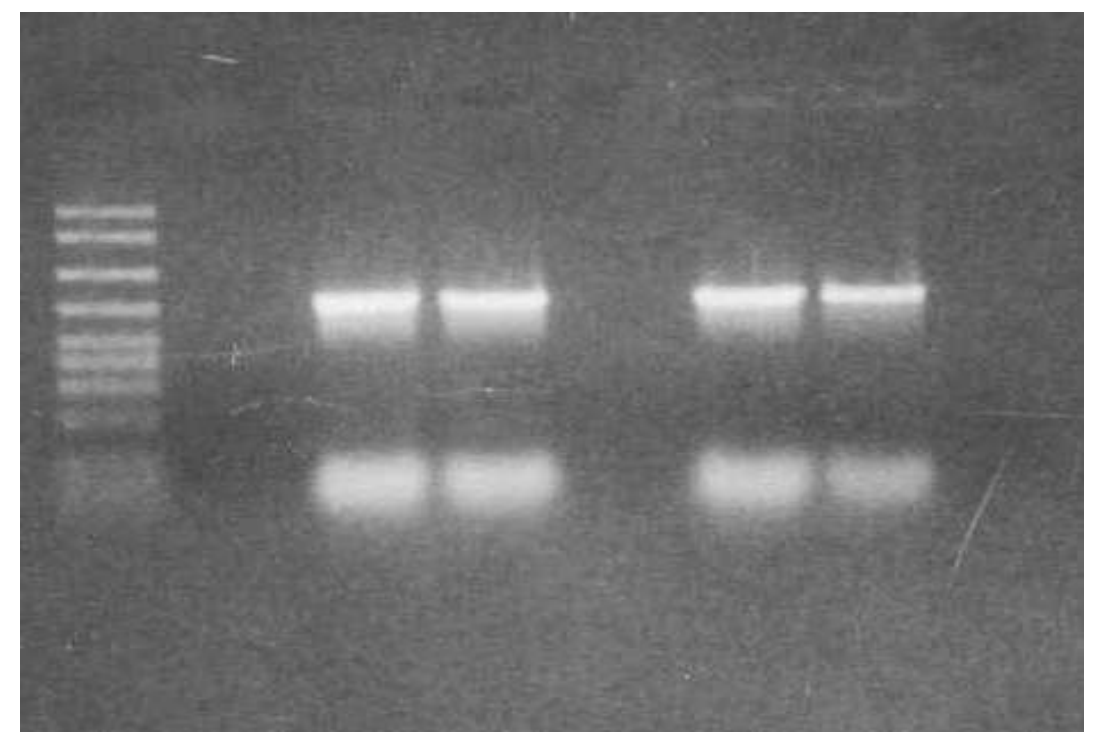

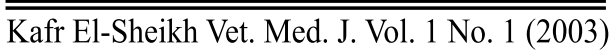


Figure (2): Original ultraviolet photograph staine d with Ethidium bromide on $1.5 \%$ agarose ge 1 


\section{REFERENCES}

- Baily, G., Krahn,J., Drasar, B.and Stoker, N. (1992): Detection of Brucella melitensis and Brucella abortus by DNA aplification.j. Trop.Med. Hyg., 95: 271-275 .

- Balakhonov,S.,Shestopalov, M. and Kalionvskii,A.(1996): Optimization of Brucella detection using polymerase chain raction . Mol. Gen. Mikrobiol- virusol., (4):33-35.

- Bricker, B.and Halling, S.(1994):Differentiation of Brucella abortus by. 1,2 and 4, Brucella melitensis, Brucella ovis, and Brucella suis by .1by PCR, J. Clin .Microbiol.,32 (11)2660-2666

- Ewlt,D. R.and Bricker,B.J.(2000): Validation of the abbreviated Brucella AMOS PCR as rapid screening method for differentiationof Brucella field strain isolates and the vaccine strains,19 and RB 51.J.Clin.Microbiol.,38 (8) : 3085-3086.

- Fekete, A. Bantle, J. and Halling, S. (1992b): Detection of Brucella by polymerase chainreaction in bovine featl and maternal tissues J.Vet. Diag. Invest.,4:79-83 .

- Fekete, A. Bantle,J. and Halling, S. and Sanborn, M.(1990):Preliminary developmentof diagnostic test for Brucella using polymer ase chain reaction. J.Appl. Bacteriol.,69(2): 216-227.

- Leal-Klevezas, D., Lopez-Merino, A. and Marti nez-Soriano, J. (1995a): Molecular detection of Brucella spp. Rapid identificaion of Br. Abortus biovar 1 using PCR. Arch. Med. Res., 26(3): 263-297.

- Leal-Klevezas,D.,Martinez-Vazquez,I.,Garcia-Cantu,J.,LopezMerino,A. and Martinez-Soriano,J.(2000) :Ues of polymerase chain reaction to detect Brucella abortus Biovar lin infected goats.Vrt.Microbiol3.75(1):91-17

- Ouahrani-Bettache,S.,Michaux,S.,Sri-

Widada,J.,Bourg,G.,Tournebize,R.,

Ramuz,M.and

Liautard,J.(1993):Ldentification and sequence analysis of $1 \mathrm{~S}$ 6501,an insertion Sequence in Brucella spp.,relationship between genomic Structure and the number of 1 S6501 copies . J. Gen.Microbiol., 139 (12) :3265-3273.

Kafr El-Sheikh Vet. Med. J. Vol. 1 No. 1 (2003) 
- Ouahrani-Bettache, S., Soubrier, M. and Liautard, J. (1996): Ls aE1 nunhomed DCD fon the dotantion and idnontification of Brucella 1 11 -160 .

- Romero, C., Gamazo, M.and Lopez-Goni, I. (1995a): Secific detection of Brucella DNA by PCR . J. Clin. Microbiol, 33 (12): 615617.

- Romero,C.,Pardo,M.,Grillo,M.,Diaz, Blasco,J.and Lo pez-Goni,I. $(1995 \mathrm{~b})$ :Evaluation of PCR and indirect enzyme-Linked Immunoaorbent assay on milk samples for diagnosis of Brucellosis in dairy cattle . J.clin. Microbiol ., 33 (12) : 3198-3200

- Sam brook, J., Fratsch,E.and Maniatis, T. ( 1989 ):Molecular cloning : a laboratory manual, 2 nd Ed. Cold spring Harbor laboratoro, cold spring harbor ,N.Y.

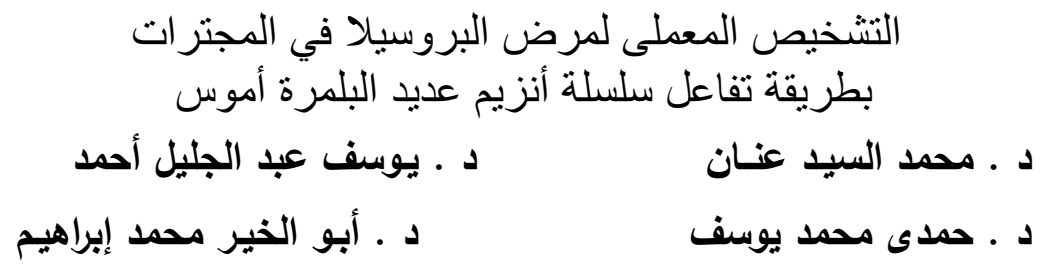

(422) عينة دم، لبن، عينات أنسجة ، مكونات معدة لجنين مجهض جمعت من مناطق مختلفة

ومتفرقة بمحافظة الثـرقية قد فحصت لنتخيص مرض البروسيلا بواسطة سلسلة أنزيم عديد البلمرة

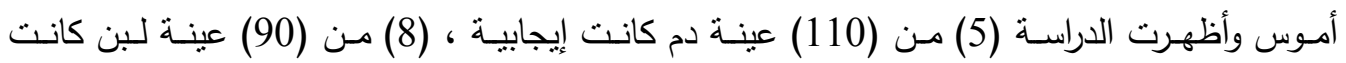

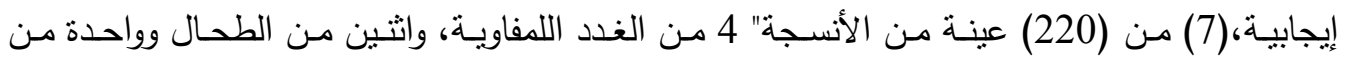
مكونات معدة لجنين مجهن" كانت إيجابية . 